\title{
Technological aspects of vegetable oils epoxidation in the presence of ion exchange resins: a review
}

\author{
Eugeniusz Milchert, Kornelia Malarczyk-Matusiak*, Marlena Musik \\ West Pomeranian University of Technology, Szczecin, Institute of Organic Chemical Technology, K. Pulaskiego 10, \\ 70-322 Szczecin, Poland \\ "Corresponding author: e-mail: kornelia.malarczyk@zut.edu.pl
}

\begin{abstract}
A review paper of the technology basics of vegetable oils epoxidation by means of peracetic or performic acid in the presence of acidic ion exchange resins has been presented. The influence of the following parameters: temperature, molar ratio of acetic acid and hydrogen peroxide to ethylenic unsaturation, catalyst loading, stirring intensity and the reaction time on a conversion of ethylenic unsaturation, the relative percentage conversion to oxirane and the iodine number was discussed. Optimal technological parameters, mechanism of epoxidation by carboxylic peracids and the possibilities of catalyst recycling have been also discussed. This review paper shows the application of epoxidized oils.
\end{abstract}

Keywords: acidic ion exchange resins, epoxidation, review, vegetable oils.

\section{INTRODUCTION}

Nowadays, it is aimed to develop the technologies enabling the production of epoxidized vegetable oils with the content of oxirane oxygen as high as possible, what is synonymous with the preparation of product with a low content of ethylenic unsaturation. These compounds exhibit a higher quality and they find a more versatile application, particularly in products with the iodine number below $10 \mathrm{~g} / 100 \mathrm{~g}^{1-3}$. The epoxidation processes of vegetable oils have been carried out by the reactions of carboxylic peracids in the presence of mineral acids ${ }^{4}$ or strongly acidic ion exchange resins ${ }^{5}$ (industrial methods) as the catalysts. The carboxylic peracids can be formed in situ in an epoxidation reactor. In the processes realized on a small scale, the following methods of epoxidation are used: chemoenzymatic, by hydrogen peroxide in the system methyltrioxorhenium(VII) $-\mathrm{CH}_{2} \mathrm{Cl}_{2} / \mathrm{H}_{2} \mathrm{O}_{2}$, by urea- $\mathrm{H}_{2} \mathrm{O}_{2}$ complex, by organic hydroperoxides or $\mathrm{H}_{2} \mathrm{O}_{2}$ in the presence of titanium as catalysts, (Ti(IV)-grafted silica, amorphous $\mathrm{Ti} / \mathrm{SiO}_{2}$ ).

\section{The importance of epoxidized vegetable oils}

Epoxidized vegetable oils are used as plasticisers and stabilizers for polyvinyl chloride and other plastics ${ }^{6,7}$. The plastics become flexible, enough to be used for the production of packaging films. They better fulfil the requirements required for high-temperature lubrication oils and they are readily biodegradable. A high reactivity of the oxirane ring in the oils causes that they are transformed in simple processes to alcohols, glycols, polyols, monoesters of glycols, diesters of glycols, alkanolamines, carbonyl compounds and the polymers of epoxide compounds ${ }^{\mathbf{8}-10}$. Epoxidised vegetable oils can be used directly as plasticizers, stabilizers of polymers ${ }^{\mathbf{1}}$ 11-13 and low-and high-temperature biolubricants ${ }^{14-16}$. Fatty and amide polyols are of a large importance due to the application in the production of polyurethanes ${ }^{1}$ and the surface active agents ${ }^{17}$. A particular importance has the production of oligoesterols and oligoetherols as an oligomeral part subjected to the reaction with isocyanates in the polyurethanes synthesis ${ }^{18,19}$. Significant amounts of oligomerols are used for the manufacture of insulating liquids ${ }^{\mathbf{1 0}}$, thermosetting composites ${ }^{\mathbf{2 0}}$ and protective coatings $^{21,} 22$ after the initiation of crosslinking by UV radiation. Fatty acid amides, obtained on the basis of linseed, soybean and canola oil after the epoxidation followed by the hydration to the glycols and further transformations are used as detergents, shampoo, lubricants, cosmetics and foam producing controllers ${ }^{23}$. Epoxidised oils with high oxirane oxygen content are considered to be of better quality ${ }^{24}$.

\section{Epoxidation by peracids}

The methods of vegetable oils epoxidation using the carboxylic peracids formed in situ or synthesized in the separate reactors (conventional treatment) are predominant among several ways of epoxidation. In these technologies, a mineral acid $\left(\mathrm{H}_{2} \mathrm{SO}_{4}, \mathrm{HNO}_{3}, \mathrm{H}_{3} \mathrm{PO}_{4}\right.$, $\mathrm{HCl}$ ), alkanesulphonic acids or strongly acidic ion exchange resins are used as catalysts in the synthesis of peracids ${ }^{4}{ }^{25-28}$. The in situ methods are mainly used for the epoxidations carried out on a large scale, realised in a batch. A primary advantage resulting from the application of the catalysts of the type of acidic ion exchange resins in a comparison to the homogeneous catalysts of the type of mineral acids relies on an improvement of the selectivity of transformation to an epoxy compound via a decrease of the rate of opening of formed oxirane ring, mainly to glycols and glycol monoesters. A smaller improvement in the selectivity transformation to oxirane was achieved after the application of neutral solvent such as benzene, toluene, hexane, heptane ${ }^{29}$. The solvent was used in the amount up to $20 \mathrm{wt} \%$ in relation to oil. This allows to increase the reaction rate and to lead the epoxidation safely at higher temperatures. A small increase in selectivity of transformation to epoxyglycerides has performed as a result of the mineral acid neutralization in the post reaction mixture ${ }^{30}$.

On an industrial scale there is carried out epoxidation of vegetable oils with nutritional properties, such as: soybean, rapeseed, palm, maize oil. Epoxyglycerides used for the above-mentioned technical applications. Currently, for these purposes are increasingly using oils that are not listed on the nutritional properties (mahua, jatropha, karanja). The process of epoxidation can be carried out as single- or two-stage. At in situ epoxida- 
tion in the reactor are mixed: oil, hydrogen peroxide, carboxylic acid and catalyst. In the two-stage process percarboxylic acid is obtained separately and introduce into the reactor containing the $\mathrm{oil}^{31}$.

The epoxidation of specified oils with high conversion of ethylenic unsaturation and high selectivity of transformation to oxirane rings requires determine the influence of technological parameters, especially: temperature, peracid - ethylene unsaturation molar ratio, reaction time, amount of catalyst and stirring speed ${ }^{\mathbf{3 2}}$. Moreover the epoxidation performed in the presence of ion exchange resins reduces the amount of wastewater as compared to mineral acids used as a catalyst, and the process can be considered as environmentally friendly. Modeling of reactor of vegetable oil epoxidation has been described in detail in the literature ${ }^{33,34}$.

\section{The epoxidation mechanism}

In the epoxidation method by carboxylic peracids proceed simultaneously two reactions the formation of peracid (1), which is consumed in the intrinsic epoxidation (2), during a contact with ethylenic unsaturation of oil (Fig. 1).

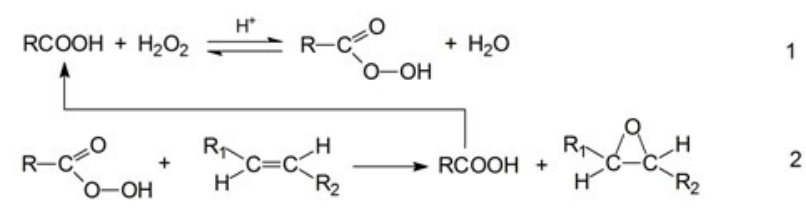

Figure 1. Scheme of vegetable oil epoxidation: peracid formation (a), epoxidation reaction (b)

The carboxylic acid, reproduced in the reaction (2) again undergoes reaction with hydrogen peroxide and new amounts of peracid are formed. The reaction (1) proceeds significantly slower in comparison with reaction (2), what limits the process. The rate of peracid formation, thereby, the process rate increases by introduction of mineral acid as a catalyst, most often sulphuric(VI) acid or strongly acidic ion exchange resins ${ }^{25,35}$. The presence of such type catalyst is not necessary in the reaction 2 . A strongly acidic catalyst accelerates the side reactions of oxirane ring opening.

\section{The side reactions}

The side reactions of epoxidation process by peracids in the presence of acidic ion exchange resins are always involve a ring opening - Figure 2.

Ring opening takes place through cleavage of one of the carbon-oxygen bonds. It can be initiated by either electrophiles or nucleophiles and catalyzed by either acids or bases. The nucleophilic attack on an epoxide is presented in Figure $3^{\mathbf{1 5}}$.

The hydrolysis leading to glycols and the acylation to hydroxy esters are the major side reactions ${ }^{36-39}$. Doll, Bantchev and Murray ${ }^{\mathbf{4 0}}$ described isomerization methods of ring oxirane to keto- and diketo derivatives in epoxy oleochemicals catalysed by bismuth(III) trifluoromethanesulfonate. Another way to limit the influence of these reactions relies on the neutralization of post-reaction solutions. In epoxidation processes realized in the presence of mineral acid $\left(\mathrm{H}_{2} \mathrm{SO}_{4}\right)$, the post-reaction stream was immediately neutralized with $10 \%$ sodium hudroxide ${ }^{\mathbf{2 6}}$,

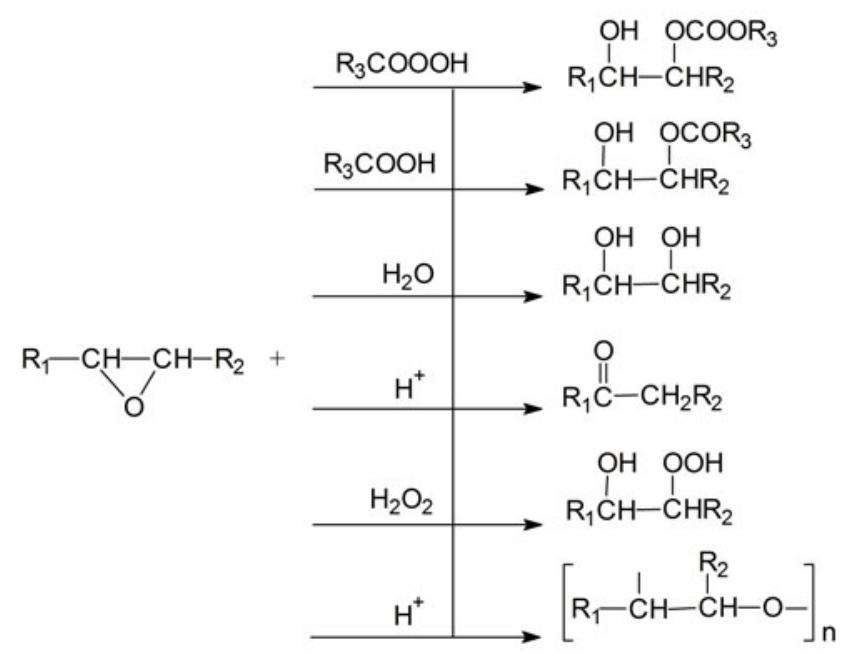

$\mathrm{H}^{+}=\mathrm{H}_{2} \mathrm{SO}_{4}, \mathrm{HNO}_{3}$, cation exchanger

Figure 2. Side reactions of epoxidation in the presence of acidic ion exchange resins

sodium bicarbonate ${ }^{39}$ or washed with warm water until it was acid free $\mathrm{38,42}^{\mathbf{4}}$. A similar effect was obtained after the replacement of mineral acid by strongly acidic ion exchange resins ${ }^{1}$. The sulfonated styrene-divinylbenzene copolymers are commonly used ${ }^{42}$. An improvement of thermal stability of epoxidized soybean oil can be achieved by running the process in the presence of acids complexing the heavy metals: nitrilotriacetic, cyclohexanediaminotetraacetic ${ }^{\mathbf{4 3}}$.

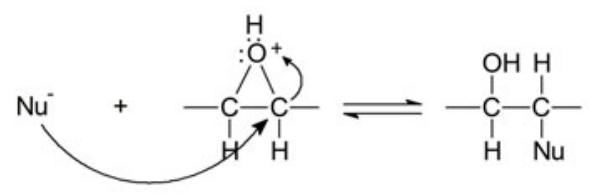

Figure 3. The nucleophilic attack on an epoxide

\section{Technological parameters of epoxidation}

A compilation of the technological parameters of epoxidation of the most important vegetable oils in the presence of ion exchange resin Amberlite IR-120 and obtained results are presented in Table 1.

As resin Amberlite IR-120 in the amount of 5-25 wt\% in relation to the epoxidized agent $\left(\mathrm{CH}_{3} \mathrm{COOH}+30 \%\right.$ $\mathrm{H}_{2} \mathrm{O}_{2}$ ) was used as the catalyst. In relation to oil, this corresponds to a value of 5-20 wt \%. The optimal amount of catalyst, which is different in dependence of the kind of oil and the remaining technological parameters was located within these ranges. A relatively large amount of the catalysts is worthy to notice. However, in some works this amount was even reduced to $2 \mathrm{wt} \%$ in relation to oil. However, an elevation of temperature to about $80^{\circ} \mathrm{C}$ and a prolongation of the reaction time to at least 8 hours was required. A lower limit of catalyst loading amounted to $10-15 \mathrm{wt} \%$ in these works ${ }^{45}$. As a rule, the epoxidizing agent was peracetic acid. This acid allowed to achieve higher selectivities of transformation to the epoxy compound in a comparison with performic acid ${ }^{\mathbf{1}}$. Moreover, the application of peracetic acid is more favourable with regard to lower costs of acetic acid regeneration in a comparison with formic acid. These costs are caused by similar boiling points of water and formic acid impeding the separation by 
Table 1. Technological parameters of vegetable oils epoxidation in the presence of acidic ion exchange resins

\begin{tabular}{|c|c|c|c|c|c|c|c|}
\hline \multicolumn{2}{|c|}{ Technological parameter } & $\begin{array}{c}\text { Canola oil } \\
\text { IN = } 112 \\
\text { [g/100 g] } \\
\text { Oleic acid } 60 \\
\text { [wt } \%]\end{array}$ & $\begin{array}{c}\text { Mahua oil } \\
\text { IN = 88 } \\
\text { [g/100 g] } \\
\text { Oleic acid } \\
46 \text { [wt } \%], \\
\text { Linoleic } \\
\text { acid } 12,74 \\
\text { [wt } \%]\end{array}$ & $\begin{array}{l}\text { Cotton seed } \\
\text { oil } \\
\qquad \begin{array}{l}\mathrm{IN}=105 \\
{[\mathrm{~g} / 100 \mathrm{~g}]}\end{array}\end{array}$ & $\begin{array}{l}\text { Soybean oil } \\
\text { IN }=125[\mathrm{~g} / 100 \mathrm{~g}]\end{array}$ & $\begin{array}{c}\text { Karanja oil } \\
\text { IN = 89 } \\
\text { [g/100 g], } \\
\text { Oleic acid } \\
62 \text { [wt } \% \text {, } \\
\text { Linoleic } \\
\text { acid } 19 \\
\text { [wt } \%] \\
\end{array}$ & $\begin{array}{c}\text { Castor oil } \\
\text { IN }=81.5[\mathrm{~g} / 100 \mathrm{~g}] \\
\text { Ricinoleic acid }(12- \\
\text {-hydroxy-9- } \\
\text {-octadecenoic) }\end{array}$ \\
\hline \multicolumn{2}{|l|}{ Literature } & 1 & 29 & 43 & 38 & 24 & 44 \\
\hline \multicolumn{2}{|c|}{$\begin{array}{l}\text { Catalyst - Amberlite IR-120 } \\
\text { [wt\%] (range and optimal) }\end{array}$} & $\begin{array}{l}6-22 \\
22^{\mathrm{a}}\end{array}$ & $\begin{array}{c}5-20 \\
16^{\mathrm{a}}\end{array}$ & $\begin{array}{c}10-25 \\
15^{\mathrm{a}}\end{array}$ & $\begin{array}{l}25 \text { relative to the } \\
\text { sum } \\
\left(\mathrm{CH}_{3} \mathrm{COOH}+30 \%\right. \\
\left.\mathrm{H}_{2} \mathrm{O}_{2}\right)\end{array}$ & $\begin{array}{c}5-20 \\
16^{\mathrm{a}}\end{array}$ & $\begin{array}{c}5-15 \\
15 \\
\text { relative to the sum } \\
\left(\mathrm{CH}_{3} \mathrm{COOH}+30 \%\right. \\
\left.\mathrm{H}_{2} \mathrm{O}_{2}\right) \\
\end{array}$ \\
\hline \multicolumn{2}{|c|}{ Epoxidizing agent } & $\begin{array}{l}\text { Peracetic } \\
\quad \text { acid } \\
\text { and } \\
\text { performic } \\
\text { acid in situ }\end{array}$ & $\begin{array}{l}\text { Peracetic } \\
\text { acid } \\
\text { in situ }\end{array}$ & $\begin{array}{l}\text { Peracetic } \\
\text { acid in situ }\end{array}$ & $\begin{array}{c}\text { Peracetic acid } \\
\text { or performic acid in } \\
\text { situ }\end{array}$ & $\begin{array}{l}\text { Peracetic } \\
\text { acid in situ }\end{array}$ & Peracetic acid in situ \\
\hline \multicolumn{2}{|c|}{$\begin{array}{l}\text { Temperature }\left[{ }^{\circ} \mathrm{C}\right] \\
\text { (range and optimal) }\end{array}$} & $\begin{array}{c}40-75 \\
65\end{array}$ & $\begin{array}{c}30-70 \\
70\end{array}$ & $\begin{array}{l}30-90 \\
70-80^{b}\end{array}$ & $\begin{array}{c}30-80 \\
80\end{array}$ & $\begin{array}{c}30-85 \\
70\end{array}$ & 50 \\
\hline \multirow{2}{*}{$\begin{array}{l}\text { Molar ratio } \\
\text { (range and } \\
\text { optimal) }\end{array}$} & $\mathrm{CH}_{3} \mathrm{COOH} / \mathrm{C}=\mathrm{C}$ & $\begin{array}{c}0.3-1.0: 1 \\
0.5: 1\end{array}$ & $\begin{array}{l}0.3-1.0: 1 \\
0.5: 1\end{array}$ & $\begin{array}{c}0.25-0.75: 1 \\
0.5: 1\end{array}$ & $0.5: 1$ & $\begin{array}{c}0.3-1: 1 \\
0.5: 1\end{array}$ & $0.5: 1$ \\
\hline & $\mathrm{H}_{2} \mathrm{O}_{2} / \mathrm{C}=\mathrm{C}$ & $\begin{array}{c}0.5-2,0: 1 \\
1.5: 1\end{array}$ & $\begin{array}{c}0.8-2.5: 1 \\
1.1: 1 \\
\end{array}$ & $\begin{array}{c}1.1-2.5: 1 \\
1.5: 1\end{array}$ & $1.5: 1$ & $\begin{array}{c}0.8-2.5: 1 \\
1.5: 1\end{array}$ & $1.5: 1$ \\
\hline \multicolumn{2}{|c|}{$\begin{array}{l}\text { Stirring speed [rpm], other } \\
\text { magnitudes }\end{array}$} & $\begin{array}{l}\text { Continuous } \\
\text { stirring }\end{array}$ & $\begin{array}{l}500-2500 \\
\text { optimally } \\
2500\end{array}$ & $\begin{array}{c}600-2400, \\
\text { optimally } \\
1800 ; \\
\text { catalyst } \\
\text { particle size } \\
120-620 \mu \mathrm{m} \\
\end{array}$ & $\begin{array}{l}\text { Toluene solvent } 44 \\
\text { wt } \% \text { relative to the } \\
\text { oil; } \\
\text { polymers are formed }\end{array}$ & $\begin{array}{l}500-2500 \\
\text { optimally } \\
1500\end{array}$ & $\begin{array}{l}1500 \\
\text { benzene solvent } 1: 1 \\
\text { by weight of oil; } \\
\text { polymers are formed }\end{array}$ \\
\hline \multicolumn{2}{|c|}{ Reaction time $[\mathrm{h}]$} & 7 & 3.5 & - & 3 & 3.5 & 8 \\
\hline \multicolumn{2}{|c|}{$\begin{array}{l}\text { Relative percentage } \\
\text { conversion to oxirane [RPC], } \\
{[\%]^{c}}\end{array}$} & 90 & 85 & 65 & 95 & 85 & 78 \\
\hline \multicolumn{2}{|c|}{$\begin{array}{l}\text { lodine number of product } \\
{[\mathrm{g} / 100 \mathrm{~g}]}\end{array}$} & 10.2 & 2.7 & 20.0 & 9.1 & - & - \\
\hline \multicolumn{2}{|c|}{$\begin{array}{l}\text { Conversion of ethylenic } \\
\text { unsaturation } \mathrm{C}[\%]^{\mathrm{d}}\end{array}$} & 88.4 & 32.0 & 65.0 & 12.7 & - & - \\
\hline
\end{tabular}

a - in relation to the amount of oil; ${ }^{b}-$ the highest epoxide number is achieved; ${ }^{c}-$ relative percentage conversion to oxirane $R_{P C}=O_{e x} / O_{t h}$ $\times 100, \mathrm{RPC}-$ relative percentage conversion, $\mathrm{O}_{\mathrm{ex}}$ - experimentally determined content of oxirane oxygen [\%/100 $\mathrm{g}$ oil], $\mathrm{O}$ th - theoretical, calculated maximal content of oxirane oxygen [\%/100 g oil], $\mathrm{O}_{\mathrm{th}}=\frac{(\mathrm{INo} / 2 \mathrm{Ai})}{100+(\mathrm{INo} / 2 \mathrm{Ai}) \mathrm{Ao}}$ Ao $\times 100, \mathrm{Ao}$ and $\mathrm{Ai}-$ atomic weight of oxygen and iodine, IN - iodine number of vegetable oil before epoxidation, IN - iodine number after epoxidation ; ${ }^{d}$ - conversion of double bonds calculated from iodine number $(\mathrm{IN}): \mathrm{C}(\%)=\left[\left(\mathrm{IN}_{\circ}-\mathrm{IN}\right) / \mathrm{IN}\right] \times 100$.

distillation methods. Moreover, the performic acid creates a greater hazard of explosive decomposition, particularly within the concentration range exceeding $50 \mathrm{wt} \%$ and at a temperature of the epoxidation $80^{\circ} \mathrm{C}^{38}$. It was confirmed experimentally in the case of soybean oil.

At temperatures up to $60^{\circ} \mathrm{C}$, the performic acid can be more efficient than peracetic acid in many epoxidations. However, at higher temperatures, the high reactivity of formic acid in the reaction with hydrogen peroxide causes, that performic acid formed and a fraction of hydrogen peroxide undergoes the decomposition before taking part in the epoxidation ${ }^{38}$. In these studies the influence of temperature on the course of processes were performed in the temperature range of $30-70^{\circ} \mathrm{C}$ or even higher $-90^{\circ} \mathrm{C}^{1,27,38,42,46}$. For most investigations peracetic acid was used as epoxidation reagent. Based on these studies, the temperature range $65-70^{\circ} \mathrm{C}$ was recognized as optimal for the reactions of canola and mahua oils by using performic acid ${ }^{1,38}$. In other works, the effect of remaining technological parameters was investigated at a constant temperature $70^{\circ} \mathrm{C}$. A temperature of $80^{\circ} \mathrm{C}$ was recognized as too high with regard to a resin destruction, causing a significant decrease of ion exchange resin activity. Mungroo et al. researches of the epoxidation of canola oil with $\mathrm{H}_{2} \mathrm{O}_{2}$ at the temperature of $65^{\circ} \mathrm{C}$, catalysed by the acidic ion exchange resin shows that the system with formic acid leads to lower conversion of ethylenic unsaturation and selectivity transformation to oxirane rings than the system with acetic acid ${ }^{1}$. According to the findings of other authors elevation of reaction temperature and extension of time results in higher oxirane content in epoxidized vegetable oils ${ }^{42,43}$.

It results, from these compilations (Table 1) that the optimal molar ratio of acetic acid to ethylenic unsaturation $\mathrm{CH}_{3} \mathrm{COOH} / \mathrm{C}=\mathrm{C}$ was found to be $0.5: 1$ in many studies. This value was determined by varying the molar ratio in the range $0.25-1.1: 1$. In the works ${ }^{38,42,44}$, the studies on the influence of remaining technological parameters were carried out at the optimal molar ratio $\mathrm{CH}_{3} \mathrm{COOH} / \mathrm{C}=\mathrm{C}$ 0.5:1.

A similar agreement, in spite of the application of different oils (canola, mahua, cottoseed, soybean, karanja), with various content of unsaturated fatty acids, occurs in the case of the molar ratio of hydrogen peroxide to ethylenic unsaturation ${ }^{1,27,32}$. The optimal ratio of $\mathrm{H}_{2} \mathrm{O}_{2} /$ $\mathrm{C}=\mathrm{C}$ amounted to $1.5: 1$ for the majority of oils. At this value, were carried out the studies of the influence of other parameters. The investigations of the effect of $\mathrm{H}_{2} \mathrm{O}_{2} / \mathrm{C}=\mathrm{C}$ molar ratio were performed in the range of 0.5-2.5:1. 
The studies of the influence of stirring speed were carried out in the range of 500-2500 rpm. The upper limit was considered to be the most advantageous. In the case of karanja oil, the optimal conditions occurred at 1500 rpm, whereas at $1800 \mathrm{rpm}$ for oil from cotton seeds.

Significant differences in the applied reaction times were noticed among the oils mentioned in Table 1. For mahua $^{27}$, karanja ${ }^{24}$ and soybean ${ }^{42}$ oils, the presented the best results were achieved after the time of 3 hours. A canola ${ }^{1}$ oil and castor ${ }^{44}$ oil required the reaction time of 7 and 8 hours respectively. It is worthy to mention that the used oils do not contain or contain a small amount of bounded linolenic acid. They are always glycerides of mono- and two-unsaturated fatty acids (oleic and linoleic) and saturated fatty acids. In the case of castor oil this is ricinoleic acid.

Vegetable oils epoxidations using peracetic acid in a longer reaction time $-7-8$ hours ${ }^{\mathbf{1}, 35}$ allows for higher conversions of ethylenic unsaturation - 88-91\% at a lower temperature $-65-70^{\circ} \mathrm{C}$ compared to processes acrried 3 hours at a slightly higher temperature $\left(80^{\circ} \mathrm{C}\right)$.

The studies on the effect of solvents (benzene, toluene) on the epoxidation of soybean oil, revealed that their use is not necessary. The relative percentage conversions to oxirane (RPC), were only slightly higher in the presence of these solvents and the conversions of ethylenic unsaturation or the other results were identical.

The work of Sinadinović-Fišer et al. $^{42}$ on the epoxidation of soybean oil catalysed by ion exchange resin showed that increasing reaction temperature, catalyst concentration and acetic acid to ethylenic unsaturation molar ratio improved conversion of ethylenic unsaturation, relative percentage conversion to oxirane (RPC) and reaction rate.

In the presented investigations, the fundamental criteria of evaluation was a relative percentage conversion to oxirane and the conversion of ethylenic unsaturation calculated based on the iodine number, in accordance with the description in Table 1. The highest RPC to oxirane amounted to $90 \%$ (canola oil, soybean oil), in the case of mahua and karanja oils it amounted to $85 \%$, whereas for castor oil amounted to $78 \%$.

The parameters presented by different research teams were convergent or similar. The identical values occur in the case of the molar ratios of acetic acid and hydrogen peroxide to ethylenic unsaturation and temperature. These values do not change in spite of different values of iodine numbers of oil used (IN $=82-130 \mathrm{~g} / 100 \mathrm{~g}$ ), different content of oleic, linoleic, linolenic and another unsaturated fatty acids.

\section{Reuse of catalyst}

The studies on the epoxidation of karanja oil ${ }^{24}$ with peracetic acid demonstrated the possibility of four times repeated recirculation of the catalyst Amberlite IR-120 in a batch process (each $3.5 \mathrm{~h}$ ). After each experiment, the catalyst required the regeneration. The regeneration relies on the filtration of catalyst, rinsing with water, diethyl ether and drying at ambient temperature. In the studies of soybean oil epoxidation ${ }^{\mathbf{4 2}}$ Amberlite IR-120 catalyst in the amount of $16 \mathrm{wt} \%$ in relation to oil was used. The epoxidation was carried out under the following technological conditions: temperature $50^{\circ} \mathrm{C}$, the molar ratio of $\mathrm{CH}_{3} \mathrm{COOH} / \mathrm{H}_{2} \mathrm{O}_{2} / \mathrm{C}=\mathrm{C}=0.5: 1.5: 1$, stirring speed $2500 \mathrm{rpm}$, reaction time 10 hours. A relative percentage conversion to oxirane (RPC) with the fresh catalyst amounted to $79 \%$ and was decreased to $73 \%$ when the catalyst was regenerated four times and then reused. The conversion calculated from iodine number was decreased from $72 \%$ to $68 \%$.

\section{Technological solutions}

A modification of the classical method (mineral acid) is the epoxidation in the presence of ion exchange resins which relies on the replacement of tank reactors with stirrer by the thin-layer epoxidation ${ }^{13,47}$. This allows to significantly shorten the time of mutual interaction of formed carboxylic acid and water with the oxirane ring. As a result, the contribution of ring opening reactions was also reduced. In the thin-layer made, the process was carried out at temperature of $38-55^{\circ} \mathrm{C}$, under pressure $2.7-53.2 \mathrm{kPa}$. The constant temperature was maintained by heating the reactor surface. This method of process operation also enables the determination of technological parameters so that during the epoxidation proceeded distilling off the water formed in the reaction and water introduced with hydrogen peroxide. The thin-layer reactor enabled to achieve the significant changes of the degree of transformation of epoxidized oil via the change of the flow rate of soybean oil and hydrogen peroxide or the molar ratio of hydrogen peroxide to oil. The selectivity of transformation to oxirane in this process was slightly higher in the presence of strongly acidic ion exchange resins (AIER) of the type of sulfonated styrene-divinylbenzene copolymers then that in the presence of homogenous catalyst of sulphuric acid type and a tank reactor. In our opinion, this method will not find wider application. Very good results can be obtained in a tank reactors with AIER after the development of most favorable technological parameters.

In the case of epoxidation of unsaturated fatty acids or unsaturated fatty acid alkyl esters by peracetic or performic acid, the introduction of catalyst in the form of mineral acid was not necessary since peracid of carboxylic acid was formed due to the influence of hydrogen peroxide $^{\mathbf{1 3}}$. In this case, it was advantageous to increase the amount of hydrogen peroxide in relation to the amount of unsaturated bonds. The rate of peracid formation was increased and the selectivity of transformation to oxirane compounds was enhanced.

The major advantage of the classical epoxidation of vegetable oils is a low cost of synthesis of peracid itself (usually acetic), the possibility of carboxylic acid recovery, its relative stability under the conditions of epoxidation operation and a relatively high yield of the process ${ }^{45}$. In the epoxidation of vegetable oils, the peracids: benzoic, fluoroacetic, m-chlorobenzoic, m-nitrobenzoic, monophthalic are of minor importance. An acid performs here a role of oxygen carrier. Simultaneously, the epoxidation reaction proceeds exothermally, which in a combination of possibility of its decompositions, creates the hazard of explosion.

The peracetic acid concentration in acetic acid during the epoxidation does not exceed $40 \mathrm{wt} \%$ at temperatures of $20-70^{\circ} \mathrm{C}$. The determination of permissible concentration of peracid and a continuous control of 
its concentration allows to counteract of this hazard. The operation of process at the optimal technological parameters and knowledge of the influence of the technological parameters on the course of epoxidation process for a particular oil or the products of its transformation (unsaturated fatty acids or alkyl esters thereof) also serves to this purpose.

It was also found, that the particles size of catalyst Amberlite IR-120 with dimensions below $120 \mu \mathrm{m}$ and above $620 \mu \mathrm{m}$ have no influence on the course of process. This allows to recognize a lack of diffusive resistance inside the particle ${ }^{45}$.

\section{CONCLUSIONS}

In the vegetable oils epoxidation processes carried out in the presence of strongly acidic ion exchange resins are obtained similar results by using acetic or performic acid. Because of the easy recovery of acetic acid from the reaction solution, and safety, acetic acid is used instead of formic acid. So far the epoxidation results in batches were described. The most suitable epoxidation temperature of frequently used vegetable oils (Table 1) using peracetic acid is $65-70^{\circ} \mathrm{C}$, with the amount of strongly acidic ion exchanger $16 \mathrm{wt} \%$. It is also important to determine the molar ratio of acetic acid to hydrogen peroxide and ethylenic unsaturation: $\mathrm{CH}_{3} \mathrm{COOH} / \mathrm{H}_{2} \mathrm{O}_{2} / \mathrm{C}=\mathrm{C}=$ $0.5: 1.5: 1$. The mixing rate should cause homogenization of the oil-water mixture and it is obtained in the range of stirring speed 1500-2500 rpm. 90\% conversion of ethylene unsaturation was obtained at these technological parameters after $8 \mathrm{~h}$. Optimal epoxidation parameters of specific oils may be different from those shown and should be determined individually for each oil. Application of AIER instead mineral acids as catalysts increases the selectivity transformation to an epoxy compounds. It is possible separation and recycling of the catalyst.

\section{LITERATURE CITED}

1. Mungroo, R., Pradhan, N.C., Goud, V.V. \& Dalai, A.K. (2008). Epoxidation of Canola Oil with Hydrogen Peroxide Catalyzed by Acidic Ion Exchange Resin. J. Am. Oil Chem. Soc. 85(9), 887-896. DOI: 10.1007/s11746-008-1277-z.

2. Güner, F.S., Yağci, Y. \& Erciyes, A.T. (2006). Polymers from Triglyceride oils. Prog. Polym. Sci. 31, 633-670. DOI: 10.1016/j.progpolymsci.2006.07.001.

3. Alam, M., Akram, D., Sharmin, E., Zafar, F. \& Ahmad, S. (2014). Vegetable oil based eco-friendly coating materials: A review article. Arab. J. Chem. 7, 469-479. DOI: 10.1016/j. arabjc.2013.12.023.

4. Dinda, A., Patwarthan, A.V., Goud, V.V. \& Pradhan, N.N. (2008). Epoxidation of cottonseed oil by aqueous hydrogen peroxide catalysed by liquid inorganic acids. Bioresour. Technol. 99, 3737-3744

5. Milchert, E., Malarczyk, K. \& Kłos, M. (2015). Technological Aspects of Chemoenzymatic Epoxidation of Fatty Acids, Fatty Acid Esters and Vegetable Oils: A Review. Molecules 20(12), 21481-21493.

6. Rios, L.A., Weckes, P., Schuster, H. \& Hoelderich, W.F. (2005). Mesoporous and amorphous Ti-silicas on the epoxidation of vegetable oils. J Catal. J. Catal. 232(1), 19-26. DOI: 10.1016/j.jcat.2005.02.011.

7. Benaniba, M.T., Belhaneche-Bensemra, N. \& Gelbard, G. (2003). Stabilization of PVC by epoxidized sunflower oil in the presence of zinc and calcium stearates. Polym. Degrad. Stabil. 82(2), 245-249. DOI: 10.1016/S0141-3910(03)00178-2.

8. Saurabh, T., Patnaik, M., Bhagt, S.L. \& Renge, V.C. (2011). Epoxidation Of Vegetable Oils: A Review. Int. J. Adv. Eng. Technol. 2(4), 491-501.

9. Metzger, J.O. \& Bornscheuer, U. (2006). Lipids as renewable resources: current state of chemical and biotechnological conversion and diversification. Appl. Microbiol. Biotechnol. 71(1), 13-22. DOI: 10.1007/s00253-006-0335-4.

10. Piazza, G.J. \& Foglia, T.A. (2005). Preparation of fatty amide polyols via epoxidation of vegetable oil amides by oat seed peroxygenase. J. Am. Oil Chem. Soc. 82(7), 481-485. DOI: 10.1007/s11746-005-1097-y.

11. Gurbanov, M.S., Chalabiev, Ch.A., Mamedov, B.A. \& Efendiev, A.A. (2005). Epoxidation of soybean oil in the course of cooxidation with hydrogen peroxide in the presence of propanoic acid and chlorinated KU-2 8 cation exchanger. Russ. J. Appl. Chem. 78, 1678-1681.

12. Carlson, K.D. \& Chang, S.P. (1985). Chemical epoxidation of a natural unsaturated epoxy seed oil fromVernonia galamensis and a look at epoxy oil markets. J. Am. Oil Chem. Soc. 62(5), 934-939. DOI: 10.1007/BF02541763.

13. Hang, X. \& Yang, H. (1999). Model for Cascade Continuous Epoxidation Process. J. Am. Oil Chem. Soc. 76, 89-92. DOI: $10.1007 / \mathrm{s} 11746-999-0052-0$.

14. Lathi, P.S. \& Mattiasson, B. (2007). Green approach for the preparation of biodegradable lubricant basestock from epoxidized vegetable oil. Appl. Catal. Envrion. 69, 207-212.

15. Salimon, J., Abdullah, B.M., Yusop, R.M. \& Salih, N. (2014). Synthesis, reactivity and application studies for different biolubricants Chem. Cent. J. 8(16), 1-11. DOI: 10.1186/1752153X-8-16.

16. Biswas, A., Adhvaryu, A., Gordon, S.H., Erhan S.Z. \& Willett, J.L. (2005). Synthesis of Diethylamine-Functionalized Soybean Oil. J. Agric. Food Chem. 53(24), 9485-9490. DOI: 10.1021/jf050731o.

17. Chlebicki, J. \& Matyschok, H. (2005). Synteza i epoksydowanie estrów etylowych nienasyconych kwasów tłuszczowych oraz ich wykorzystanie w produkcji związków powierzchniowo czynnych. Przem. Chem. 84(12), 933-938.

18. Ligadas, G., Ronda, J.C., Galia, M. \& Cadiz, V. (2010). Plant oils as platform chemicals for polyurethane synthesis:current state-of-the-art. Biomacromolecules 11(11), 2825-2835. DOI: 10.1021/bm100839x.

19. Zhang, Ch., Madbouly, S.A. \& Kessler, M.R. (2015). Biobased polyurethanes prepared from different vegetable oils. Appl. Math. Interfaces 7(2), 1226-1233. DOI: 10.1021/ am5071333.

20. Roth, M., Tang, Q., Malherbe, R. \& Schoenenberger, C. (2001). U.S. Patent No. 6,194,490 B1. Brewster, NY (US): Vantico, Inc.

21. Thames, S.F. \& Yu, H. (1999). Cationic UV-cured coatings of epoxide-containing vegetable oils. Surf. Coat. Tech. 115(2), 208-214. DOI: 10.1016/S0257-8972(99)00244-3.

22. Rüsch gen Klaas, M. \& Warwel, S. (1999). Complete and partial epoxidation of plant oil by lipase-catalysed perhydrolysis. Ind. Crop. Prod. 9(2), 125-132. DOI: 10.1016/S09266690(98)00023-5.

23. Mc Kenna, A.L., Fatty amides, synthesis, properties, reactions and applications. Witco Chemical Corporation, Humko Chemical. Division, Memphis, 1982, 111-194.

24. Goud, V.V., Patwardhan, A.V., Dinda, S. \& Pradhan, N.C. (2007). Epoxidation of karanja (Pongamia glabra) oil catalysed by acidic ion exchange resin. Eur. J. Lipid Sci. Technol. 109, 575-584. DOI: 10.1002/ejlt.200600298.

25. Goud, V.V., Patwardhan, A.V., Dinda, S. \& Pradhan, N.C. (2007). Kinetics of epoxidation of jatropha oil with peroxyacetic and peroxyformic acid catalysed by acidic ion exchange resin. Chem. Eng. Sci. 62(15), 4065-4076. DOI: 10.1016/j.ces.2007.04.038. 
26. Milchert, E. \& Smagowicz, A. (2009). The Influence of Reaction Parameters on the Epoxidation of Rapeseed Oil with Peracetic Acid. J. Am. Oil Chem. Soc. 86, 1227-1233. DOI: 10.1007/s11746-009-1455-7.

27. Goud, V.V., Patwardhan, A.V. \& Pradhan, N.C. (2006). Studies on the epoxidation of mahua oil (Madhumica indica) by hydrogen peroxide. Biores. Technol. 97(12), 1365-1371. DOI: 10.1016/j.biortech.2005.07.004.

28. Schmitz, W.R. \& Wallace, J.G. (1954). Epoxidation of methyl oleate with hydrogen peroxide. J. Am. Oil Chem. Soc. 31(9), 363-365. DOI: 10.1007/BF02545510.

29. Matyschok, H. \& Chlebicki, J. (2001). Synthesis and epoxidation of methyl esters of unsaturated fatty acids. Pol. J. Appl. Chem. 45(1-2), 13-23.

30. Milchert, E. \& Kłos, M. (2013). Epoksydacja zużytych olejów roślinnych kwasem nadoctowym. Przem. Chem. 92, 670-674.

31. Gurbanov, M.S. \& Mamedov, M.A. (2009). Epoxidation of flax oil with hydrogen peroxide in a conjugate system in the presence of acetic acid and chlorinated cation exchanger KU-2×8 as catalyst. Russ. J. Appl. Chem. 82(8), 1483-1487.

32. Milchert, E., Smagowicz, A. \& Lewandowski, G. (2010). Optimization of the Epoxidation of Rapeseed Oil with Peracetic Acid. Org. Proc. Res. Dev. 14, 1094-1101. DOI: 10.1021/ op900240p.

33. Zheng, J.L., Wärnå, J., Salmi, T., Burel, F., Taouk, B. \& Leveneur, S. (2016). Kinetic modeling strategy for an exothermic multiphase reactor system: Application to vegetable oils epoxidation using Prileschajew method. AIChE Journal 62(3), 726-741. DOI: 10.1002/aic.15037.

34. Leveneur, S., Zheng, J., Taouk, B., Burel, F., Wärnå, J. \& Salmi, T. (2014). Interaction of thermal and kinetic parameters for a liquid-liquid reaction system: Application to vegetable oils epoxidation by peroxycarboxylic acid. J. Taiwan Inst. Chem. E. 45, 1449-1458. DOI: 10.1016/j.jtice.2014.01.015.

35. Goud, V.V., Patwardhan, A.V. \& Pradhan, N.C. (2006). Epoxidation of Karanja (Pongamia glabra) Oil by $\mathrm{H}_{2} \mathrm{O}_{2}$. J. Am. Oil Chem. Soc. 83(7), 635-640. DOI: 10.1007/s11746-006-1250-7.

36. Goud, V.V., Patwardhan, A.V. \& Pradhan, N.C. (2007). Kinetics of in situ Epoxidation of Natural Unsaturated Triglycerides Catalyzed by Acidic Ion Exchange Resin. Ind. Eng. Chem. Res. 46(10), 3078-3085. DOI: 10.1021/ie060146s.

37. Campanella, A. \& Baltanás, M.A. (2006). Degradation of the oxirane ring of epoxidized vegetable oils in liquid-liquid heterogeneous reaction systems. Chem. Eng. J. 118(3), 141-152. DOI: 10.1016/j.cej.2006.01.010.

38. Petrović, Z.S., Zlatanić, A., Lava, C.C. \& Sinadinović-Fišer, S. (2002). Epoxidation of soybean oil in toluene with peroxoacetic and peroxoformic acids - kinetics and side reactions. Eur. J. Lipid Sci. Technol. 104(5), 293-299. DOI: 10.1002/1438-9312(200205)104:5<293::AID-EJLT293 > 3.0.CO;2-W.

39. Rangarajan, B., Havey, A., Grulke, E.A. \& Culnan, P.D. (1995). Kinetic parameters of a two-phase model forin situ epoxidation of soybean oil. J. Am. Oil Chem. Soc. 72(10), 1161-1169. DOI: 10.1007/BF02540983.

40. Doll, K.M., Bantchev, G.B. \& Murray, R.E. Bismuth, (2013). Bismuth(III) Trifluoromethanesulfonate Catalyzed Ring-Opening Reaction of Mono Epoxy Oleochemicals To Form Keto and Diketo Derivatives. ACS Sust. Chem. Eng. 1, 39-45. DOI: 10.1021/sc300092r.

41. Carlson, K.D., Kleiman, R. \& Bagby, M.O. (1994). Epoxidation of Lesquerella and Limnanthes (Meadowfoam) Oils. $J$. Am. Oil Chem. Soc. 71(2), 175-182. DOI: 10.1007/BF02541553.

42. Sinadinović-Fišer, S., Janković, M. \& Petrović, Z.S. (2001). Kinetics of in situ epoxidation of soybean oil in bulk catalyzed by ion exchange resin. J. Am. Oil Chem. Soc. 78(7), 725-731. DOI: 10.1007/s11746-001-0333-9.
43. Jourdan-Laforte, E. (1980). U.S. Patent No. 4,215,058 A. Paris: L'Air Liquide, Societe Anonyme pourl'Etude et l'Exploitation des Brevets Georges Claude.

44. Janković, M.R., Sinadinović-Fišer, S.V. \& Govedarica, O.M. (2014). Kinetics of the Epoxidation of Castor Oil with Peracetic Acid Formed in Situ in the Presence of an Ion-Exchange Resin. Ind. Eng. Chem. Res. 53(22), 9357-9364. DOI: 10.1021/ie500876a.

45. Dinda, S., Goud, V.V., Patwardhan, A.V. \& Pradhan, N.C. (2011). Selective epoxidation of natural triglycerides using acidic ion exchange resin as catalyst. Asia-Pacific J. Chem. Eng. 6(6), 870-878. DOI: 10.1002/apj.466.

46. Sinadinović-Fišer, S., Janković, M. \& Borota, O. (2012). Epoxidation of castor oil with peracetic acid formed in situ in the presence of an ion exchange resin. Chem. Eng. Proc. 62, 106-113. DOI: 10.1016/j.cep.2012.08.005.

47. Nowak, J. A., Zillner, T.A. \& Mullin, L.P. (2004). U.S. Patent No. 6,734,315 B1. Chicago: The C.P. Hall Company. 